\title{
EVALUASI RANSUM MENGANDUNG Indigofera zollingeriana TERHADAP ANAK KAMBING LEPAS SAPIH
}

\author{
Suharlina ${ }^{1,2)}$, D.A. Astuti ${ }^{3)}$, Nahrowi ${ }^{3)}$, A. Jayanegara3), L. Abdullah ${ }^{3)}$ \\ ${ }^{1}$ Program Studi Peternakan Sekolah Tinggi Pertanian Kutai Timur, Sangatta Utara 75611 \\ E-mail : suharlina@stiperkutim.ac.id \\ 2Program Studi IImu Nutrisi dan Pakan Sekolah Pascasarjana IPB, Bogor 16680 \\ ${ }^{3}$ Departemen IImu Nutrisi dan Teknologi Pakan Fakultas Peternakan IPB, Bogor 16680
}

\begin{abstract}
ABSTRAK
Penelitian bertujuan mengevaluasi nutrisi ransum mengandung Indigofera zollingeriana terhadap performa anak kambing lepas sapih. Desain percobaan menggunakan rancangan acak lengkap (RAL) dengan 4 perlakuan ransum mengandung I.zollingeriana. Sebanyak 16 ekor anak kambing peranakan etawah (PE) betina lepas sapih (14-21 kg) dipelihara selama 8 minggu.I. zollingeriana diformulasi dalam konsentrat R1, R2, R3, R4 dengan proporsi masing-masing o, 20, 40 dan 60\% I. zollingeriana. Ransum diberikan berupa konsentrat dan rumput gajah $(\mathrm{RG})$, yaituI $\left(75 \% \mathrm{R} 1+25 \%\right.$ rumput gajah), $\mathrm{I}_{20}(75 \% \mathrm{R} 2+25 \% \mathrm{RG}), \mathrm{I}_{40}\left(75 \% \mathrm{R}_{3}+\right.$ $25 \% \mathrm{RG}), \mathrm{I}_{60}(75 \% \mathrm{R} 4+25 \% \mathrm{RG})$.Peubah yang diamati adalah konsumsi dan kecernaan protein, utilisasi nitrogen, nutrien darah, pertambahan bobot badan (PBB) harian dan efisiensi ransum. Data dianalisis menggunakan analisis ragam. Hasil penelitian menunjukkan konsumsi protein kasar $\mathrm{I}_{40}$ lebih tinggi $(\mathrm{P}<0.05)$ dibandingkan $\mathrm{I}_{\mathrm{o}}$. Kecernaan bahan organik $\mathrm{I}_{20}$ lebih tinggi $(\mathrm{P}<0.05)$ dari $\mathrm{I}_{60}$. Kecernaan protein kasar $\mathrm{I}_{20}$ dan $\mathrm{I}_{40}$ lebih tinggi $(\mathrm{P}<0.05)$ dibandingkan $\mathrm{I}_{\mathrm{o}}$ dan $\mathrm{I}_{60}$. Total digestible nutrient ransum $\mathrm{I}_{\mathrm{O}}$ dan $\mathrm{I}_{20}$ lebih tinggi $(\mathrm{P}<0.05)$ dibandingkan $\mathrm{I}_{40}$ dan $\mathrm{I}_{60}$. Konsumsi $\mathrm{N} \mathrm{I}_{0}$ lebih rendah $(\mathrm{P}<0.05)$ dari $\mathrm{I}_{40}$. Retensi $\mathrm{N} \mathrm{I}_{40}$ lebih tinggi $(\mathrm{P}<0.05)$ dibandingkan $\mathrm{I}_{\mathrm{O}}$ dan $\mathrm{I}_{60}$, sedangkan $\mathrm{I}_{20}$ lebih tinggi $(\mathrm{P}<0.05)$ dibandingkan $\mathrm{I}_{0}$. Net nitrogen utilization $\mathrm{I}_{20}$ dan $\mathrm{I}_{40}$ lebih tinggi $(\mathrm{P}<0.05)$ dibandingkan $\mathrm{I}_{\mathrm{O}}$ dan $\mathrm{I}_{60}$. Konsentrasi total protein, albumin dan immonoglobulin $\mathrm{G}$ plasma darah anak kambing tidak berbeda. Kolesterol darah $\mathrm{I}_{40}$ dan $\mathrm{I}_{60}$ lebih rendah $(\mathrm{P}<0.05) \mathrm{I}_{\mathrm{O}}$ dan $\mathrm{I}_{20}$. PBB harian $\mathrm{I}_{20}$ lebih tinggi $(\mathrm{P}<0.05)$ dibandingkan $\mathrm{I}_{\mathrm{O}}$ dan $\mathrm{I}_{60}$. Efisiensi $\mathrm{I}_{20}$ berbeda $(\mathrm{P}<0,05)$ dari ransum lainnya.
\end{abstract}

Kata kunci: Indigofera zollingeriana, kambing perah,utilisasi nitrogen

\section{ABSTRACT}

This study was objected to evaluate the nutritional values of ration containing Indigofera zollingeriana to post-weaning goat kids performans. Randomized completely design were used to four types of rations. The 16 heads of ettawah gradebreed post-weaning goad kids (14-21 body weight) were maintained during 8 weeks. I. zollingeriana forage were formulated into R1, R2, R3, and R4 concentrate feeds with proportion $\mathrm{O}, 20,40$, and $60 \% \mathrm{I}$. zollingeriana, respectively. The rations were $\mathrm{I}_{\mathrm{O}}\left(75 \% \mathrm{R} 1+25 \%\right.$ napier grass), $\mathrm{I}_{20}(75 \%$ $\mathrm{R} 2+25 \%$ napier grass), $\mathrm{I}_{40}$ (75\% R3 $+25 \%$ napier grass), $\mathrm{I}_{60}$ ( $75 \% \mathrm{R} 4+25 \%$ napier grass), respectively. The variables observed were nutrient intake, digestibility, nitrogen utilization, blood nutrients, average daily gain (ADG) and feed efficiency. The data were analyzed using analysis of variance. The result showed that the crude protein $(\mathrm{CP})$ intake of $\mathrm{I}_{40}$ was higher $(\mathrm{P}<0.05)$ than $\mathrm{I}_{0}$. The organic matter digestibility value of $\mathrm{I}_{20}$ was higher $(\mathrm{P}<0.05)$ than $\mathrm{I}_{60}$. The $\mathrm{CP}$ digestibility values of $\mathrm{I}_{20}$ and $\mathrm{I}_{40}$ were higher $(\mathrm{P}<0.05)$ than $\mathrm{I}_{\mathrm{o}}$ and $\mathrm{I}_{60}$. The total digestible nutrient value of $\mathrm{I}_{0}$ and $\mathrm{I}_{20}$ were higher $(\mathrm{P}<0.05)$ than $\mathrm{I}_{40}$ and $\mathrm{I}_{60}$. The nitrogen $(\mathrm{N})$ intake of $\mathrm{I}_{\mathrm{O}}$ was less than $(\mathrm{P}<0.05) \mathrm{I}_{40}$. The $\mathrm{N}$ retention of $\mathrm{I}_{40}$ was higher $(\mathrm{P}<0.05)$ than $\mathrm{I}_{0}$ and $\mathrm{I}_{60}$, while $\mathrm{I}_{20}$ was higher $(\mathrm{P}<0.05)$ than $\mathrm{I}_{0}$. The net nitrogen utilization of $\mathrm{I}_{20}$ and $\mathrm{I}_{40}$ were higher than $\mathrm{I}_{\mathrm{O}}$ and $\mathrm{I}_{60}$. There were no significantly differences on total protein, albumin and immunoglobulin $\mathrm{G}$ values of blood serum. The cholesterol serum values of $\mathrm{I}_{40}$ and $\mathrm{I}_{60}$ were less $(\mathrm{P}<0.05)$ than $\mathrm{I}_{0}$ and $\mathrm{I}_{20}$. The ADG of $\mathrm{I}_{20}$ was higher $(\mathrm{P}<0.05)$ than $\mathrm{I}_{0}$ and $\mathrm{I}_{60}$. The feed efficiency of $\mathrm{I}_{20}$ was highest $(\mathrm{P}<0.05)$ than other rations.

Key words: dairy goat, Indigofera zollingeriana, nitrogen utilization 


\section{PENDAHULUAN}

Masa depan keberhasilan peternakan kambing perah salah satunya bergantung pada keberhasilan program pemeliharaan anak dan kambing dara yang nantinya akan digunakan sebagai pengganti induk. Peternakan kambing perah umumnya menggunakan ternak untuk menghasilkan susu selama empat periode laktasi. Usaha untuk menjaga stabilitas produksi diperlukan penggantian beberapa induk setiap tahun. Karenanya pemeliharaan terhadap anak dan kambing dara sangat diperlukan untuk menjaga produktivitas ternak. Ternak lepas sapih memerlukan perhatian optimal untuk mempersiapkan ternak sesuai tujuan produksi. Pertumbuhan pasca sapih sangat ditentukan oleh bangsa, jenis kelamin, mutu ransum yang diberikan, umur dan berat sapih serta lingkungan misalnya suhu udara, kondisi kandang, pengendalian parasit dan penyakit lainnya. Ransum memegang peranan penting dalam menyediakan nutrien untuk mendukung keberhasilan produksi ternak ruminansia. Pemberian ransum berkualitas merupakan salah satu cara mempersiapkan ternak betina sebagai indukan yang baik. Kebutuhan ternak untuk masa pertumbuhan memerlukan ransum yang berkualitas mengandung protein tinggi.

Produktivitas kambing perah di daerah tropis seperti Indonesia dapat ditingkatkan dengan introduksi hijauan leguminosa yang mengandung protein tinggi terutama pada saat musim kemarau ketika kualitas hijauan sangat rendah. Salah satu leguminosa yang berpotensi sebagai pakan kambing perah adalah Indigofera zollingeriana. Tanaman ini memiliki pertumbuhan cepat pada interval defoliasi 60 hari dan produksi bahan kering 51ton/ ha/tahun (Abdullah 2010), sangat adaptif terhadap kesuburan tanah yang rendah, mudah dan murah dalam perawatannya dan memiliki protensi produksi benih sepanjang musim(Abdullah dan Suharlina 2010). Pemberian pellet daun I. zollingerianapada kambing perah laktasi meningkatkan produksi susu, efisiensi ransum dan efisiensi nutrien masing-masing secara berurutan 26\%, 15-23\% dan 5-9\% (Abdullah et $a l$. 2012).Penelitian ini dilakukan untuk mengevaluasi ransum mengandung $I$. zollingerianapada anak kambing perah betina lepas sapih.

\section{MATERI DAN METODE}

Penelitian ini dilaksanakan pada bulan JanuariMaret 2015, di laboratorium Ilmu Nutrisi Ternak Daging dan Kerja Fakultas peternakan IPB.Hijauan I. zollingeriana diformulasi dalam konsentrat R1, $\mathrm{R} 2, \mathrm{R} 3$ dan $\mathrm{R} 4$ dengan proporsi o, 20, 40 dan $60 \%$ I. zollingeriana. Bahan konsentrat digiling hingga melewati saringan ukuran $1 \mathrm{~mm}$ dan dicampur hingga homogen, kemudian campuran bahan dipellet dengan diameter $5 \mathrm{~mm}$.Komposisi nutrien masing-masing ransum dianalisis secara proksimat (AOAC 1990) (Tabel 1).

Tabel 1 Komposisi Nutrien Ransum Penelitian Anak Kambing Lepas Sapih

\begin{tabular}{lrrrr}
\hline $\begin{array}{l}\text { Kandungan } \\
\text { Nutrien (\%) }\end{array}$ & \multicolumn{1}{c}{$\mathrm{I}_{0}$} & \multicolumn{1}{c}{$\mathrm{I}_{20}$} & \multicolumn{1}{c}{$\mathrm{I}_{40}$} & \multicolumn{1}{c}{$\mathrm{I}_{60}$} \\
\hline Abu & 10,96 & 9,41 & 11,02 & 9,54 \\
PK & 14,95 & 16,21 & 16,58 & 16,51 \\
LK & 5,34 & 4,42 & 3,87 & 3,45 \\
SK & 15,31 & 15,19 & 16,49 & 17,86 \\
BeTN & 53,44 & 54,77 & 52,03 & 52,65 \\
TDN & 67,76 & 68,70 & 65,75 & 69,19 \\
Ca & 0,71 & 0,84 & 1,24 & 1,50 \\
P & 0,57 & 0,30 & 0,27 & 0,37 \\
\hline
\end{tabular}

$I_{0}: 75 \%$ R1 (konsentrat mengandung $0 \%$ I. zollingeriana) $+25 \%$ rumput gajah $I_{20}: 75 \%$ R2 (konsentrat mengandung $20 \%$ I. zollingeriana) $+25 \%$ rumput gajah

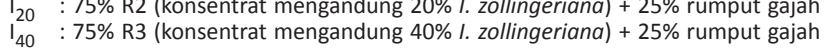
$I_{60}: 75 \%$ R4 (konsentrat mengandung $60 \%$ I. zollingeriana) $+25 \%$ rumput gajah

Sebanyak 16 ekor anak kambing peranakan etawah (PE) betina lepas sapih dengan bobot badan ratarata $16 \mathrm{~kg}$ dipelihara selama 8 minggu. Penelitian menggunakan rancangan acak lengkap (RAL) dengan 4 perlakuan ransum mengandung hijauan I. zollingeriana. Satu perlakuan terdiri dari 4 ekor ternak. Pemeliharaan selama 8 minggu, 3 minggu masa adaptasi, 5 minggu perlakuan. Konsumsi bahan kering per hari sebesar $4 \%$ dari bobot badan (Ensminger 2002). Ransum yang diberikan berupa $75 \%$ konsentrat mengandung hijauan I. zollingeriana dan 25\% rumput gajah yang sudah dicacah 2-3 cm. Air minum diberikan ad libitum. Konsumsi ransum dan sisa ransum ditimbang setiap hari. Pengukuran koleksi feses dan urin selama 5 hari berturut-turut.

\section{Peubah yang Diamati}

1. Jumlah konsumsi ransum (gram) dihitung pada setiap ekor (e) ternak setiap hari (h). Perhitungan konsumsi ransum $\left(\mathrm{g} \mathrm{e}^{-1} \mathrm{~h}^{-1}\right)$ bertujuan untuk mengetahui konsumsi bahan kering (BK) dan nutrien ransum.

2. Koefisien cerna bahan kering (KCBK), bahan organik(KCBO) dan protein(KCPK):

3. Pertambahan bobot badan harian $(\mathrm{PBBH})$, dan efisiensi ransum dihitung dengan rumus sebagai berikut:

$$
\text { PBBH }(g \text { e } h)=\frac{\text { BB akhir }(g \text { e })-B B \text { awal }(g \text { e })}{\text { Lama penggemukan }(\mathrm{h})}
$$

Efisiensi ransum $(\%)=\frac{\text { Pertambahan bobot badan }(g \text { e } h)}{\text { Konsumsi bahan kering }(g \text { e } h)} \times 100 \%(2)$ 
4. Utilisasi Nitrogen (N) (Church dan Pond 1982) a. Konsumsi Nitrogen (N) $\left(\mathrm{g} \mathrm{e}^{-1} \mathrm{~h}^{-1}\right)$

Konsumsi $\mathrm{N}=\frac{\text { Konsumsi BK }\left(\mathrm{g} \mathrm{e}^{-1} \mathrm{~h}^{-1}\right) \times \text { Protein Kasar ransum (\%) }}{6,25}$

b. Retensi $\mathrm{N}\left(\mathrm{g} \mathrm{e}^{-1} \mathrm{~h}^{-1}\right)$

c. Retensi $\mathrm{N}=$

Konsumsi $\mathrm{N}\left(\mathrm{g} \mathrm{e}^{-1} \mathrm{~h}^{-1}\right)-\mathrm{N}$ feses $\left(\mathrm{g} \mathrm{e}^{-1} \mathrm{~h}^{-1}\right)-$ $\mathrm{N}$ urin $\left(\mathrm{g} \mathrm{e}^{-1} \mathrm{~h}^{-1}\right)$

d. Net Nitrogen Utilization (NNU) (Siti et al. 2013)

$$
\text { (NNU) }(\%)=\frac{\text { Retensi N }\left(\mathrm{g} \mathrm{e}^{-1} \mathrm{~h}^{-1}\right)}{\text { Konsumsi N }\left(\mathrm{g} \mathrm{e}^{-1} \mathrm{~h}^{-1}\right)} \times 100 \%
$$

5. Kandungan total protein, albumin, dan kolesterol darah: Darah diambil pada daerah vena jugularis menggunakan spoit steril volume $3 \mathrm{~mL}$ dan ditampung pada tabung steril tanpa antikoagulan. Serum darah diperoleh dengan melakukan sentrifuse sampel darah menggunakan sentrifuse kecepatan 3634 kali selama 15 menit.

a. Total Protein. Total protein darah ditentukan dengan metode biuret. Kadar total protein dihitung dengan rumus:

$$
\text { Total protein }\left(\mathrm{gdL}^{-1}\right)=\frac{\text { Absorbansi sampel }}{\text { Absorbansi standar }} \times 8
$$

b. Albumin. Kadar albumin darah ditentukan dengan metode BCG. Kadar albumin dihitung dengan rumus:

$$
\text { Albumin }\left(\mathrm{gdL}^{-1}\right)=\frac{\text { Absorbansi sampel }}{\text { Absorbansi standar }} \times 4
$$

c. Kolesterol: Kadar kolesterol ditentukan dengan metode CHOD-PAP. Kadar kolesterol dihitung dengan rumus:

$$
\text { Kolestrol }\left(\mathrm{mgdL}^{-1}\right)=\frac{\text { Absorbansi sampel }}{\text { Absorbansi standar }} \times 200
$$

6. Immunoglobilin $\mathrm{G}$ (IgG). Kadar IgG dianalisis menggunakan metode Indirect Sandwich Elisa.

\section{Analisis Data}

Data yang diperoleh dianalisis menggunakan anilis sidik ragam, dengan bantuan SPSS versi 16 . Perbedaan yang signifikan pada perlakuan dilanjutkan dengan uji beda nyata terkecil.

\section{HASIL DAN PEMBAHASAN}

\section{Konsumsi Ransum}

Konsumsi ransum dipengaruhi oleh faktor ransum dan ternak. Ternak lebih suka mengonsumsi ransum berkualitas dengan tingkat palatabilitas tinggi. Faktor ternak yang mempengaruhi tingkat konsumsi adalah kondisi fisiologi ternak yang membutuhkan zat makanan dengan jumlah berbeda pada setiap fasenya (Orskov 2001). Konsumsi bahan kering (BK) dan bahan organik (BO) anak kambing lepas

\begin{tabular}{|c|c|c|c|c|c|}
\hline & $\mathrm{I}_{0}$ & $\mathrm{I}_{20}$ & $\mathrm{I}_{40}$ & $I_{60}$ & SEM \\
\hline \multicolumn{6}{|l|}{ Konsumsi $\left(\mathrm{g} \mathrm{e}^{-1} \mathrm{~h}^{-1}\right)$} \\
\hline Bahan Kering & 634,80 & 688,50 & 794,97 & 727,27 & 27,62 \\
\hline Bahan Organik & 568,27 & 623,00 & 707,59 & 659,16 & 24,39 \\
\hline Protein Kasar & $91,77^{\mathrm{b}}$ & $112,96^{\mathrm{ab}}$ & $131,47^{\mathrm{a}}$ & $117,65^{\mathrm{ab}}$ & 5,41 \\
\hline$\%$ konsumsi BK** & 3,06 & 3,13 & 3,61 & 3,48 & \\
\hline \multicolumn{6}{|l|}{ Kecernaan (\%) } \\
\hline Bahan Kering & 71,66 & 74,75 & 67,73 & 65,40 & 1,57 \\
\hline Bahan Organik & $70,23^{\mathrm{ab}}$ & $74,31^{\mathrm{a}}$ & $67,21^{\mathrm{ab}}$ & $63,32^{\mathrm{b}}$ & 1,62 \\
\hline Protein Kasar & $75,62^{b}$ & $84,23^{a}$ & $85,03^{a}$ & $74,23^{b}$ & 1,45 \\
\hline TDN & $78,82^{\mathrm{ab}}$ & $80,57^{a}$ & $75,86^{b}$ & $76,24^{b}$ & 0,78 \\
\hline \multicolumn{6}{|l|}{ Utilisasi Nitrogen } \\
\hline $\begin{array}{l}\text { Konsumsi N } \\
\left(\mathrm{g} \mathrm{e}^{-1} \mathrm{~h}^{-1}\right)\end{array}$ & $14,68^{b}$ & $18,08^{\mathrm{ab}}$ & $21,04^{\mathrm{a}}$ & $18,82^{\mathrm{ab}}$ & 0,87 \\
\hline $\mathrm{N}$ teretensi $\left(\mathrm{g} \mathrm{e}^{-1} \mathrm{~h}^{-1}\right)$ & $8,70^{c}$ & $13,55^{\mathrm{ab}}$ & $15,60^{\mathrm{a}}$ & $11,11^{b c}$ & 0,88 \\
\hline NNU (\%) & $58,96^{\mathrm{b}}$ & $74,93^{\mathrm{a}}$ & $73,54^{\mathrm{a}}$ & $58,85^{\mathrm{b}}$ & 2,17 \\
\hline \multicolumn{6}{|c|}{ Profil nutrien darah $\left(\mathrm{mg} \mathrm{mL}^{-1}\right)$} \\
\hline Total Protein & 68,2 & 64,3 & 65,7 & 74,8 & 0,28 \\
\hline Albumin & 33,1 & 32,4 & 29,3 & 33,1 & 0,08 \\
\hline $\begin{array}{l}\text { Imunoglobulin } G \\
(\operatorname{IgG})\end{array}$ & 14,80 & 12,50 & 18,68 & 14,93 & 1,19 \\
\hline Kolesterol & $0,80^{a}$ & $0,78^{\mathrm{a}}$ & $0,52^{\mathrm{b}}$ & $0,57^{b}$ & 4,13 \\
\hline \multicolumn{6}{|c|}{ PBB dan efisiensi Ransum } \\
\hline PBB (g/ekor/hari) & $75,66^{\mathrm{b}}$ & $115,13^{a}$ & $92,11^{\mathrm{ab}}$ & $88,82^{b}$ & 5,02 \\
\hline Efesiensi ransum & $0,13^{b}$ & $0,19^{a}$ & $0,13^{b}$ & $0,14^{b}$ & 0,01 \\
\hline
\end{tabular}

Tabel 2 Konsumsi, kecernaan, utilisasi nitrogen, profil nutrien darahd, PBB dan efisiensi ransum mengandung Indigofera zollingeriana terhadap anak kambing PE lepas sapih

a,b : superskrip berbeda pada baris yang sama menunjukkan perbedaan $(P<0.05)$ $I_{0}:$ : $75 \%$ konsentrat mengandung $0 \% \mathrm{I}$. zollingeriana $+25 \%$ rumput gajah I : $75 \%$ konsentrat mengandung $20 \%$ I. zollingeriana $+25 \%$ rumput gajah $\mathrm{I}_{40}: 75 \%$ konsentrat mengandung $40 \%$ I. zollingeriana $+25 \%$ rumput gajah $I_{60}: 75 \%$ konsentrat mengandung $60 \%$ I. zollingeriana $+25 \%$ rumput gajah ** : persentase konsumsi bahan kering (BK) terhadap bobot badan ternak TDN (\%) : PK $_{\text {tercerna }}+2.25 \mathrm{LK}_{\text {tercerna }}+\mathrm{SK}_{\text {tercerna }}+\mathrm{BETN}_{\text {terce }}$ SEM : standart error of means (standar eror dari rata-rata); $n=4$

sapih masing-masing berkisar 634-794 dan 568-707 $\mathrm{g} \mathrm{e}^{-1} \mathrm{~h}^{-1}$ (Tabel 2). Konsumsi BK dalam penelitian ini diurutkan dari $\mathrm{I}_{0}, \mathrm{I}_{20}, \mathrm{I}_{40}$, dan $\mathrm{I}_{60}$ masing-masing 3.06, 3.13, 3.61, dan 3.48\% dari bobot badan.

Tidak terdapat perbedaan pada konsumsi BK dan BO. Hal tersebut karena bobot anak kambing yang digunakan dalam penelitian ini relatif seragam sehingga jumlah rataan $\mathrm{BK}$ dan $\mathrm{BO}$ ransum yang dikonsumsi ransum dalam penelitian ini memiliki nilai yang sama. Konsumsi PK anak kambing yang diberi ransum $\mathrm{I}_{40}$ lebih tinggi $(\mathrm{P}<0.05)$ dibandingkan $\mathrm{I}_{\mathrm{O}}$ sedangkan konsumsi $\mathrm{PK}$ ternak yang diberi ransum $\mathrm{I}_{20}$ dan $\mathrm{I}_{60}$ tidak berbeda dengan $\mathrm{I}_{\mathrm{O}}$ (Tabel 2). Hal tersebut karena kandungan protein dalam ransum $\mathrm{I}_{\mathrm{o}}$ lebih rendah dibandingkan ransum lainnya. Penambahan I. zollingeriana dalam ransum meningkatkan kandungan protein ransum, sehingga juga meningkatkan jumlah konsumsi protein ransum.

Pemberian ransum secara terpisah antara rumput dan konsentrat memberikan peluang bagi ternak untuk memilih ransum yang lebih disukai. Ternak yang diberi ransum $\mathrm{I}_{\mathrm{O}}$ memiliki rasio konsumsi konsentrat dan rumput gajah 64:36. Artinya, konsentrat tanpa I. zollingeriana kurang disukai sehingga kambing 
lebih banyak mengkonsumsi rumput gajah. Hal tersebut berbeda $(\mathrm{P}<0.05)$ dengan kambing yang diberi ransum $\mathrm{I}_{20}$ dan $\mathrm{I}_{40}$ yang memiliki rasio konsumsi konsentrat dan rumput gajah pada kisaran 75:25, sedangkan pada $\mathrm{I}_{60}$ 70:30. Penambahan $I$. zollingeriana yang tinggi pada $\mathrm{I}_{60}$ pada penelitian ini mulai terjadi penurunan konsumsi konsentrat tersebut, yang mungkin disebabkan oleh palatabilitas konsentrat karena mengandung I. zollingeriana yang tinggi. Dinamika konsumsi ransum yang demikian menyebabkan tidak adanya perbedaan pada konsumsi BK dan BO ransum tetapi terdapat perbedaan pada konsumsi PK.

\section{Kecernaan Ransum}

Kecernaan ransum menggambarkan tingkat nilai nutrien yang dapat dimanfaatkan oleh tubuh ternak untuk kebutuhan hidup pokok maupun produksi. Nilai kecernaan yang tinggi mengindikasikan bahwa ransum yang diberikan pada ternak memberikan manfaat yang tinggi.Kecernaan bahan kering (KCBK) dan bahan organik (KCBO) masing-masing berkisar 65.40-74.75 dan 63.32-74.31\% (Tabel 2). Nilai KCBK ransum dalam penelitian ini tidak berbeda nyata, sedangkan nilai $\mathrm{KCBO} \mathrm{I}_{20}$ lebih tinggi $(\mathrm{P}<0.05)$ dari $\mathrm{I}_{60}$ tetapi tidak berbeda dengan $\mathrm{I}_{\mathrm{O}}$ dan $\mathrm{I}_{40}$. Nilai $\mathrm{KCBO}$ yang sama dengan ransum kontrol $\left(\mathrm{I}_{\mathrm{O}}\right)$ mengindikasikan bahwa penambahan I. zollingeriana dapat mencukupi beberapa nutrien bahan lain dari ransum kontrol.

Kebutuhan protein ternak ruminansia dan nilai protein ransum diekspresikan sebagai protein kasar tercerna untuk waktu yang lama. Kecernaan protein kasar (KCPK) digunakan sebagai standar untuk evaluasi kebutuhan protein untuk ruminansia.KCPK $\mathrm{I}_{20}$ dan $\mathrm{I}_{40}$ lebih tinggi $(\mathrm{P}<0,05)$ dibandingkan $\mathrm{I}_{\mathrm{O}}$ dan $\mathrm{I}_{60}$ (Tabel 2). Rendahnya nilai KCPK pada ransum $\mathrm{I}_{60}$ berhubungan dengan peran faktor pembatas pada legum I. zoliingeriana dan peningkatan fraksi serat. I. zollingeriana mengandung metabolit sekunder berupa tanin dalam jumlah kecil, tetapi pertambahan proporsi I. zollingeriana dalam ransum juga akan meningkatkan jumlah tanin dalam ransum sehingga menurunkan kecernaan protein ransum.

Total digestible nutrien (TDN) atau total nutrien tercerna merupakan gambaran nutrien tercerna yang sebanding dengan energi tercerna atau digestible energy (DE). TDN diekspresikan dalam bentuk unit ataupun dalam persen. Persentase TDN dalam penelitian ini yaitu ransum $\mathrm{I}_{\mathrm{O}}$ dan $\mathrm{I}_{20}$ lebih tinggi $(\mathrm{P}<0.05)$ dibandingkan $\mathrm{I}_{40}$ dan $\mathrm{I}_{60}$ (Tabel 2).

\section{Utilisasi Nitrogen}

Konsumsi nitrogen $(\mathrm{N})$ dalam ransum berkisar 14.68-21.04 $\mathrm{g} \mathrm{e}^{-1} \mathrm{~h}^{-1}$ (Tabel 2). Konsumsi $\mathrm{N}$ pada $\mathrm{I}_{\mathrm{O}}$ lebih rendah $(\mathrm{P}<0.05)$ dibandingkan $\mathrm{I}_{40}$ tetapi tidak berbeda dengan $\mathrm{I}_{20}$ dan $\mathrm{I}_{60}$. Konsumsi $\mathrm{N}$ pada $\mathrm{I}_{20}$ dan $\mathrm{I}_{60}$ tidak berbeda dengan $\mathrm{I}_{40}$. Nilai konsumsi $\mathrm{N}$ memiliki pola yang sama dengan konsumsi protein, hal tersebut karena $\mathrm{N}$ merupakan salah satu unsur penyusun senyawa protein. Konsumsi N pada $\mathrm{I}_{\mathrm{O}}$ memperlihatkan nilai paling rendah karena konsumsi $\mathrm{BK} \mathrm{I}_{\mathrm{O}}$ dalam penelitian ini juga lebih rendah dibandingkan ransum lainnya.

Retensi nitrogen $(\mathrm{N})$ merupakan salah satu metode yang umum digunakan untuk mengevaluasi kualitas protein.Nilai $\mathrm{N}$ terentensi dalam penelitian ini berkisar 8.70-15.60 $\mathrm{ge}^{-1} \mathrm{~h}^{-1}$ (Tabel 2). Nilai $\mathrm{N}$ terentensi diurutkan mulai yang paling tinggi hingga terendah yaitu $\mathrm{I}_{40}, \mathrm{I}_{20}, \mathrm{I}_{60}$ dan $\mathrm{I}_{\mathrm{o}}$. Nilai $\mathrm{N}$ terentensi $\mathrm{I}_{40}$ lebih tinggi $(\mathrm{P}<0.05)$ dibandingkan $\mathrm{I}_{\mathrm{O}}$ dan $\mathrm{I}_{60}$, sedangkan $\mathrm{I}_{20}$ lebih tinggi $(\mathrm{P}<0.05)$ dibandingkan $\mathrm{I}_{\mathrm{O}}$ tetapi tidak berbeda dengan $\mathrm{I}_{40}$ dan $\mathrm{I}_{60}$. Semakin tinggi nilai retensi $\mathrm{N}$ mengindikasikan bahwa metabolisme PK dalam tubuh ternak semakin efisien. Penambahan I. zollingeriana pada $\mathrm{I}_{40}$ dan $\mathrm{I}_{20}$ menghasilkan nilai $\mathrm{N}$ teretensi paling lebih efisien dibandingkan ransum tanpa $I$. zollingeriana $\left(\mathrm{I}_{\mathrm{O}}\right)$. Penambahan $I$. zollingeriana pada $\mathrm{I}_{60}$, tidak efisien untuk ternak lepas sapih meskipun proporsi I. zollingeriana dalam ransum lebih tinggi.

Net Nitrogen Ulitilization (NNU) digunakan untuk mengukur kualitas protein yang merupakan persentase jumlah $\mathrm{N}$ teretensi terhadap konsumsi N. Nilai NNU dalam penelitian ini berkisar $58.85^{-}$ $74.93 \%$ (Tabel 2). Nilai NNU $\mathrm{I}_{20}$ dan $\mathrm{I}_{40}$ lebih tinggi $(\mathrm{P}<0.05)$ dibandingkan $\mathrm{I}_{0}$ dan $\mathrm{I}_{60}$. Nilai NNU dapat dimaknai bahwa seberapa banyak $\mathrm{N}$ yang terkonsumsi dapat diretensi (dimanfaatkan) dalam tubuh ternak. Penambahan I. zollingeriana pada $\mathrm{I}_{20}$ dan $\mathrm{I}_{40}$ menunjukkan indikasi sumbangan $\mathrm{N}$ yang lebih efisien dalam pemanfaatannya dalam tubuh ternak dibandingkan ransum $\mathrm{I}_{60}$ maupun ransum tanpa $I$. zollingeriana $\mathrm{I}_{0}$.

\section{Nutrien Darah}

Fraksi utama protein dalam darah, yaitu albumin, globulin dan fibrinogen. Albumin, fibrinogen, dan globulin (50-80\% globulin) disintesis di organ hati, sedangkan sisa globulin lainnya dibentuk di jaringan limfoid.Pengukuran konsentrasi protein total dalam darah merupakan salah satu metode untuk mengevaluasi secara tidak langsung status kekebalan ternak. Konsentrasi protein total darah anak kambing dalam penelitian ini berkisar $6.43-74.8 \mathrm{mg} \mathrm{mL}^{-1}$ (Tabel 2). Nilai konsentrasi total protein dalam darah sangat tergantung pada jumlah $\mathrm{N}$ atau asam amino yang terserap melalui dinding rumen maupun dinding usus dan tingkat mobilisasi pemakaian dari komponen protein tersebut. Nilai konsentrasi protein total yang sama dalam penelitian ini dapat diartikan bahwa 
secara fisiologis anak kambing berusaha menyerap komponen protein dalam jumlah yang relatif sama dan disimpan sementara dalam darah menunggu perintah susunan saraf pusat melalui hipotalamus terhadap pemanfaatannya.

Albumin merupakan bagian protein darah yang dapat memberikan gambaran sebagai salah satu indikator kekebalan tubuh (Astuti et al. 2009). Kadar albumin plasma darah anak kambing PE yang dalam penelitian ini berkisar 29.3-33.1 $\mathrm{mg} \mathrm{mL}^{-1}$ (Tabel 2). Tidak terdapat perbedaan konsentrasi albumin diantara ransum yang mengandung $I$. zollingeriana dengan ransum kontrol $\left(\mathrm{I}_{0}\right)$. Hal tersebut sejalan dengan nilai konsentrasi protein total plasma darah karena albumin plasma darah merupakan bagian dari total protein plasma darah.

Pengukuran konsentrasi protein total dapat digunakan sebagai indikator besar kecilnya konsentrasi imunoglobulin (Ig) di dalam serum karena kontribusi konsentrasi imunoglobulin terhadap konsentrasi protein total di dalam darah sangat besar (Selim et al. 1995). Immunoglobulin disebut juga antibodi merupakan suatu fraksi plasma (serum) yang bereaksi secara khusus dengan antigen yang merangsang produksinya.Imunoglobulin diproduksi oleh sel-sel sistem kekebalan yang disebut limfosit B. Imunoglobulin G (IgG) merupakan reaksi imun yang diproduksi terbanyak sebagai antibodi utama dalam proses sekunder dan merupakan pertahanan penting terhadap bakteri dan virus. Konsentrasi IgG pada plasma darah anak kambing PE lepas sapih berkisar 12.50-18.68 mg mL $\mathrm{mL}^{-1}$. Tidak terdapat perbedaan konsentrasi IgG diantara perlakuan ransum yang diberikan pada ternak dalam penelitian ini. Tranfer pasif imunitas dinyatakan gagal jika konsentrasi imonoglobulin serum atau plasma $<10$ mg mL $\mathrm{m}^{-1}$ (McGuirk dan Collins 2004) yang juga dikaitkan dengan kasus peningkatan risiko morbiditas dan mortalitas, penurunan laju pertumbuhan, dan penurunan produksi susu pada laktasi pertama (Faber et al. 2005). Konsentrasi IgG plasma darah anak kambing lepas sapih dalam penelitian melewati batas minimal berlangsungnya tranfer pasif imunitas. Hal tersebut mengindikasikan bahwa pemberian $I$. zollingeriana tidak mengganggu kesehatan anak kambing PE lepas sapih.

Kadar kolesterol darah anak kambing PE dalam penelitian ini berkisar $0.52-0.80 \mathrm{mg} \mathrm{mL}^{-1}$ (Tabel 2). Kambing yang diberi ransum $\mathrm{I}_{40}$ dan $\mathrm{I}_{60}$ menunjukkan kandungan kolesterol darah yang lebih rendah $(\mathrm{P}<0.05)$ dibandingkan $\mathrm{I}_{\mathrm{O}}$ dan $\mathrm{I}_{20}$. Hal tersebut dikarenakan ransum $\mathrm{I}_{40}$ dan $\mathrm{I}_{60}$ lebih banyak mengandung hijauan I. zollingeriana. Selain itu kandungan serat kasar ransum $\mathrm{I}_{40}$ dan $\mathrm{I}_{60}$ lebih tinggi (Tabel 1). Serat kasar ransum dapat menurunkan kadar kolesterol dalam serum dengan cara meningkatkan ekskresi asam empedu, yang merupakan produk metabolisme kolesterol (Piliang dan Djojosoebagio 2006).Penelitian lain pada domba menunjukkan bahwa domba yang diberikan 100\% rumput lapang menghasilkan kadar kolesterol darah sebesar $0.61 \mathrm{mg} \mathrm{mL}^{-1}$ (Astuti dan Suprayogi 2005). Gambaran kolesterol darah akibat ransum yang diberikan pada anak kambing tersebut dapat menggambarkan bahwa ransum $\mathrm{I}_{20}$ sesuai untuk kebutuhan anak kambing betina yang membutuhkan kolesterol cukup tinggi karena dipersiapkan sebagai calon induk.

\section{PBB Harian dan Efisiensi Ransum}

Konsumsi ternak pada masa pertumbuhan umumnya lebih tinggi dari ternak dewasa sehingga memerlukan zat-zat makanan yang relatif lebih tinggi per unit beratbadannya.Pertumbuhan pada umumya dinyatakan dengan mengukur kenaikan berat badan dan biasanya dinyatakan sebagai pertambahan berat badan (PBB) harian.Pertambahan bobot badan (PBB) harian anak kambing $\mathrm{PE}$ betina lepas sapih berkisar antara 75.66-115.13 $\mathrm{g} \mathrm{e}^{1} \mathrm{~h}^{-1}$ (Tabel 2). PBB harian anak kambing yang diberi ransum $\mathrm{I}_{20}$ lebih tinggi $(\mathrm{P}<0.05)$ dibandingkan $\mathrm{I}_{0}$ dan $\mathrm{I}_{60}$ tetapi tidak berbeda nyata dengan $\mathrm{I}_{40}$. Hal tersebut berkaitan dengan nilai KCPK maupun retensi nitrogen $(\mathrm{N})$ yang dimiliki masing-masing ransum perlakuan. Beberapa amino asam dan peptida digunakan untuk produksi susu dan pertumbuhan. Anak kambing lepas sapih lebih banyak menggunakan asam amino untuk pertumbuhan, sehingga hal tersebut berkaitan langsung dengan pertambahan bobot badan harian. Ransum $\mathrm{I}_{60}$ meskipun mengandung PK lebih tinggi tetapi nilai KCPK dan $\mathrm{N}$ teretensi relatif rendah sehingga tidak menghasilkan PBB harian yang optimal.

Tinggi rendahnya PPB harian tidak hanya dipengaruhi oleh konsumsi $\mathrm{N}$ tetapi juga energi ransum. Peningkatan konsumsi nitrogen tidak selalu disertai dengan peningkatan bobot badan terutama jika energi di dalam ransum rendah. Energi ransum dalam penelitian ini digambarkan dengan nilai TDN ransum. Ransum $\mathrm{I}_{20}$ memiliki nilai TDN lebih tinggi dibandingkan dengan $\mathrm{I}_{40}$ dan $\mathrm{I}_{60}$, sehingga menghasilkan PBB yang tinggi. Ransum $\mathrm{I}_{40}$ memiliki nilai TDN yang lebih rendah (Tabel 2), sehingga PBB yang dihasilkan oleh ransum $\mathrm{I}_{40}$ diindikasikan lebih banyak peran protein. Ransum $\mathrm{I}_{60}$ memiliki jumlah protein ransum paling tinggi tetapi KCPK, jumlah retensi $\mathrm{N}$ dan TDN yang rendah menghasilkan PBB yang juga rendah. Ransum kontrol tanpa $I$. zollingeriana $\mathrm{I}_{\mathrm{O}}$, meskipun memiliki TDN yang tinggi tetapi kandungan $\mathrm{PK}, \mathrm{KCPK}$, retensi $\mathrm{N}$ rendah mengakibatkan PBB harian ternak yang rendah. 
Dinamika hubungan protein dan energi terhadap PBB harian anak kambing memberikan makna bahwa untuk mendapatkan PBB harian yang optimal diperlukan imbangan energi dan protein. Imbangan energi dan protein berpengaruh terhadap rasio $\mathrm{C}-\mathrm{N}$ yang diperlukan oleh mikroba rumen untuk sintesis protein dan menghasilkan enzim. Mikroba rumen berperan dalam proses degradasi ransum dalam rumen. Rasio C-N yang seimbang mengakibatkan proses degradasi ransum yang efisien. Penambahan I. zollingeriana pada $\mathrm{I}_{20}$ dan $\mathrm{I}_{40}$ menggambarkan keseimbangan rasio $\mathrm{C}-\mathrm{N}$ sehingga proses degradasi ransum berjalan efisien dan menghasilkan PBB harian yang lebih baik.

I. zollingeriana telah diketahui mengandung protein tinggi, menghasilkan produksi gas total yang tinggi, dan mudah terdegradasi dalam rumen karena mengandung bahan organik tinggi berupa protein sebagai sumber nitrogen $(\mathrm{N})$, dan kadar serat kasar rendah (Suharlina et al., 2016a; 2016b). Hal tersebut menjadi keunggulan, tetapi juga dapat menjadi kelemahan I. zollingeriana jika pemberiannya pada ternak tidak ditangani dengan baik. Penanganan yang perlu dilakukan supaya I. zollingeriana dapat dimanfaatkan dengan optimal oleh ternak yaitu dengan mencampurkan dengan bahan pakan yang mengandung energi tinggi sebagai sumber karbon (C) seperti silase jagung, onggok atau tepung singkong. Keseimbangan $\mathrm{C}$ dan $\mathrm{N}$ dalam ekosistem rumen dapat dimanfaatkan oleh mikroba rumen untuk memperbanyak diri, sehingga dapat menjadi sumber protein mikroba bagi ternak. Hal tersebut mendukung mendukung penjelasan keterkaitan antara rasio $\mathrm{C}-\mathrm{N}$ terhadap pertambahan bobot badan anak kambing lepas sapih pada Tabel 2.

Efisiensi ransum merupakan rasio antara pertambahan bobot badan yang dihasilkan dengan jumlah ransum yang dikonsumsi.Semakin besar nilai efisiensi ransum, maka penggunaan ransum semakin baik dalam pertumbuhan ternak.Ransum $\mathrm{I}_{20}$ menunjukkan nilai efisiensi ransum yang tinggi dalam penelitian ini adalah $\mathrm{I}_{20}$ (Tabel 2).

\section{KESIMPULAN}

Penambahan I. zollingeriana dalam ransum anak kambing PE lepas sapih dapat memperbaiki nilai konsumsi protein kasar (PK) ransum, kecernaan bahan organik (KCBO), utilisasi protein ransum dan menjaga kesehatan ternak. Pemberian ransum mengandung $20 \%$ I. zollingeriana untuk anak kambing PE lepas sapih memperlihatkan nilai terbaik terhadap pertambahan bobot badan harian dan efisiensi penggunaan ransum. Penambahan $I$. zollingeriana dalam ransum sebanyak $20 \%\left(\mathrm{I}_{20}\right)$ sesuai untuk anak kambing betina yang dipersiapkan sebagai calon induk. Penambahan 40\% I. zollingeriana dalam ransum induk laktasi meningkatkan nilai kecernaan, produksi dan komposisi susu serta efisiensi pemanfaatan nutrien ransum terhadap produksi dan komposisi susu.

\section{UCAPAN TERIMA KASIH}

Penulis mengucapkan terima kasih kepada PT Kaltim Prima Coal melalui program beasiswa pendidikan doktor sehingga penelitian ini dapat dilaksanakan.

\section{DAFTAR PUSTAKA}

Abdullah, L. 2010. Herbage production and quality of shrub indigofera treated by different concentration of foliar fertilizer.Med Pet. 33(3):169-175.

Abdullah, L., Suharlina,A. Tarigan,D.S. Budhie. 2012. Use of Indigofera zollingeriana as forage protein source in dairy goat ration. In: Proceeding of the ${ }^{1}$ st Asia Dairy Goat Conference; 2012Apr 9-12; Kuala Lumpur, Malaysia. Kuala Lumpur (MY): UPM and FAO. pp 72-74.

Abdullah, L., Suharlina. 2010. Herbage yield and quality of two vegetative parts of Indigofera at different time of first regrowth defoliation. Med Pet. 33(1):44-49.

[AOAC] Association of Official Analytical chemist. 1990. Official Methods of Analysis. Washington DC (USA): Wilson Blv.

Astuti, D.A., dan A. Suprayogi. 2005. Produktivitas domba lokal yang dipelihara di lingkungan hutan tropis gunung walat, Sukabumi Jawa Barat. In: Proceeding DAAD-SEAGWorkshop; 2005April; Bogor Indonesia. Bogor (I mkD): SEAG.

Astuti, D.A., E.Wina, B. Haryanto, S. Suharti. 2009. Performa dan profil beberapa komponen darah sapi peranakan ongole yang diberi pakan mengandung lerak (Sapindus rarak De Candole). Med Pet. 32(1):63-70.

Church, D.C., W.G. Pond. 1982. Basic Animal Nutrition and Feeding. Canada (USA): John Wiley and Sons.

Ensminger, M. E. 2002. Sheep and Goat (Animal Agriculture Series). Danvile (USA): Interstate PublishersInc.

Faber, S.N., N. E. Faber, T. C. McCauley, Ax RL. 2005. Effects of colostrum ingestion on lactational performance. Prof Anim Sci. 21:420-425.

McGuirk, S. M., and M. Collins. 2004. Managing the production, storage, and delivery of colostrum. Vet Clin North Am Food Anim Pract. 20:593-603.

Orskov, E. R. 2001.The Feeding of Ruminants 
Principles and Practice. Welton Lincoln (UK): Chalcombe Publication.

Piliang, W. G., Al Haj S. Djojosubagio. 2006. Fisiologi Nutrisi. Bogor (ID): IPB Pr.

Selim, S. A., B. P. Smith, J. S. Cullor, P. Blanchard, T. B. Farver, R. Hoffman, G. Dilling, L. Roden, B. Wilgenburg. 1995. Serum immunoglobulins in calves : their effects and two easy, reliable means of measurement. Vet Med. 90:387-404.

Siti, N.W., N. M. Witariadi, N. K. Mardewi, K. N. N. Candrasih, I M. Mudita, N. G. K. Roni,I G. L. O. Cakra, dan N. M. Suci Sukmawati. 2013. Utilisasi nitrogen dan komposisitubuh kambing peranakan etawah yang diberi pakan hijauan rumput lapangandengan suplementasi dedak padi. Majalah Ilmiah Peternakan. Volume 16 Nomor 1.

Suharlina, D. A. Astuti, Nahrowi, A. Jayanegara, L. Abdullah. 2016a. Nutritional evaluation of dairy goat rations containing Indigofera zollingeriana by using in vitro Rumen Fermentation Technique (RUSITEC). Int J Dairy Sci. 11 (3): 100-105.

Suharlina, D. A. Astuti, Nahrowi, A. Jayanegara, L. Abdullah. 2016b. In vitro evaluation of concentrate feed containing Indigofera zollingeriana in goat. JITAA.41 (4): 196-203. 